\title{
Determination of Shelf Life for Butter and Cheese Products in Actual and Accelerated Conditions
}

\author{
Jung-Min Park, Jin-Ho Shin, Da-Jeong Bak, Na-kyeong Kim, Kwang-Sei Lim¹, \\ Cheul-Young Yang ${ }^{2}$, and Jin-Man Kim* \\ Department of Food Science and Biotechnology of Animal Resources, Konkuk University, Seoul 143-701, Korea \\ ${ }^{I} R \& D$ Center, Maeil Dairies Co. Ltd., Pyeongtaek 451-861, Korea \\ ${ }^{2}$ Department of Food Technology and Services, Eulji University, Seongnam 461-713, Korea
}

\begin{abstract}
The aim of this study was to estimate the shelf life of butter and cheese products, with shelf life being a guide used to determine the storage period of food before deterioration. Butter and cheese samples stored at $10^{\circ} \mathrm{C}$ and $15^{\circ} \mathrm{C}$ had a shelf life of $221 \mathrm{~d}$, while those stored at $25^{\circ} \mathrm{C}$ and $35^{\circ} \mathrm{C}$ had a shelf life of $109 \mathrm{~d}$. Quality changes, including total cell count, coliform counts, Listeria monocytogenes counts, acid value, moisture content, $\mathrm{pH}$, acidity and overall sensory evaluation, were monitored. In order to pass the overall sensory evaluation, a quality score of 5 points on a 9-point scale was required. For other quality criteria, legal quality limits were established based on the "Process Criteria and Ingredient Standard of Livestock Products" by the Animal, Plant and Fisheries Quarantine and Inspection Agency (Republic of Korea). The nonlegal quality limit was estimated by regression analysis between non-quality criteria (y) and overall sensory evaluation (x). The shelf life was estimated based on the number of days that the product passed the quality limit of the quality criteria. The shelf life of samples stored at $10^{\circ} \mathrm{C}, 15^{\circ} \mathrm{C}, 25^{\circ} \mathrm{C}$ and $35^{\circ} \mathrm{C}$ was $21.94,17.18,6.10$ and 0.58 mon, respectively, for butter and $10.81,9.47,4.64$ and 0.20 mon, respectively, for cheese.
\end{abstract}

Key words: shelf life, butter, cheese, quality limit, accelerated conditions, guideline

\section{Introduction}

The domestic food hygiene research in Korea has advanced in recent years, but food poisoning is still present due to clustering of dietary life and growth of the food service industry (Park et al., 2001; Kwun and Lee, 2007; Groth, 2014). Due to this issue, food safety and sanitation methods are very important factor for consumers in purchasing food and beverages (Lee, 2001), and the growing awareness of food safety among consumers has led to increased food product safety. The safety among consumers has led to the increase in food product safety. According to Park and Min (1995), nearly $69.2 \%$ of consumers check food labeling at the time of purchase. The food label provides information regarding the product name, raw material, expiration date, preservation method, nutritional ingredients, and other details (Bernues et al., 2003), and contains important information that aids the con-

*Corresponding author: Jin-Man Kim, Department of Food Science and Biotechnology of Animal Resources, Konkuk University, Seoul 143-701, Korea. Tel: 82-2-450-3688, Fax: 82-2455-1044, E-mail: jinmkim@konkuk.ac.kr sumer in ascertaining food safety (Lee and Kim, 2001). According to a survey on food safety awareness conducted by the Korean National Council of Consumer Organizations in $2009,25.4 \%$ of consumers considered the expiration date the most important aspect of food labeling when purchasing food products; this aspect scored higher than price, raw material, origin, and food additives. A recent study by Kim and Lee (2010) also suggests that consumers consider the expiration date as the most important aspect on the labeling, above all other details (Sikorski et al., 1989). Based on these reports, it is clear that the expiration date is a crucial factor for purchase decisions, clearly demonstrated by the fact that consumers tend to buy products that have relatively long expiration dates, though there are no issues with the consumption of a product close to its expiration date (Evert-Arriagada et al., 2014). Products that are past their expiration dates are taken off the shelves and discarded. According to the Korean Consumer Agency, more than 65 million tons of food are disposed of each year due to surpassed expiration dates, resulting in high resource waste. Section 2 of the Livestock Labeling Standards, by the Animal and Plant Quarantine Agency, 
defines expiration dates as the period between production and purchase of the product during which the product can be legally sold. The expiration date is also referred to as the "Sell-by Date", where the product can be offered to the consumer (Codex, General Standard for the Labeling of Prepackaged Food). The expiration date also discloses the longest period of time the product can be sold to a consumer, as determined by the manufacturer and based on processing standards and compositional specifications (Labuza and $\mathrm{Fu}, 1993$ ). Originally, the government recommended a certain expiration date for each type of product, until the release of expiration dates on July 1, 2002. As companies are now allowed to set the expiration dates for individual products, a growing number of companies have determined expiration dates of products without scientific evidence, while other companies copied the expiration dates of competitors. Therefore, a guideline is needed in setting expiration dates. The Korea Food and Drug Administration have proposed the development of scientifically determined guidelines for expiration dates, as well as guidelines for the storage of dairy products and other livestock products. The Product Liability Law (PL) was passed shortly after the release of expiration dates, causing the manufacturers to be responsible for mishaps due to incorrect expiration dates, and satisfying consumers by providing products with longer expiration dates and better quality control. However, small businesses, which constitute up to $70 \%$ of livestock production in Korea, may lack the necessary funding and/or advancements to conduct proper experiments. Also they are alleged to set expiration dates without scientific evidence (Hwang and Park, 2007). Issues occur when small businesses determine the expiration date of their products based solely on competing products from larger companies without considering the manufacturing process or the packaging of the product. Accordingly, the Korea Food \& Drug Administration has provided a scientifically sound process of determining food product expiration dates via the "Guideline for Establishment of Shelf-life of Foods". For livestock products, however, specific regulations have not been set for expiration dates or experimental manuals, resulting in difficulties. Butter and cheese are more likely to be imported and exported than other dairy foods, such as whole milk and yogurt. When butter and cheese are circulated, the risk of deterioration increases due to long distances and time (Krause et al., 2008). Although there have been several studies focused on the shelf life of whole milk (Chung et al., 2002; Lim, 2003; Choi, 2004), studies on other dairy products, such as butter and cheese, for determining shelf life are lacking. Therefore, we used legal and non-legal (not illegal) methods in this study to conduct quality tests of butter and cheese stored at $10^{\circ} \mathrm{C}, 15^{\circ} \mathrm{C}, 25^{\circ} \mathrm{C}$, and $35^{\circ} \mathrm{C}$, respectively, to identify a scientifically valid expiration date.

\section{Materials and Methods}

\section{Storage conditions and materials}

Milk product samples were chosen from dairy product companies in Korea, from brands consumed the most by the Korean population as assessed by market research. Cheese is typically pasteurized for $5 \mathrm{~min}$ at $80^{\circ} \mathrm{C}$; a softprocess cheese consumed by many consumers in Korea was used. Butter is typically pasteurized at $85^{\circ} \mathrm{C}$. Butter (unsalted) is pasteurized for $15 \mathrm{~s}$ at $85^{\circ} \mathrm{C}$. Samples were transferred immediately to the laboratory under refrigerated conditions, and the initial sample quality analyzed. Butter and cheese were both stored at $10^{\circ} \mathrm{C}, 15^{\circ} \mathrm{C}, 25^{\circ} \mathrm{C}$, and $35^{\circ} \mathrm{C}$ respectively. The experiment was performed at a circulating temperature of $10^{\circ} \mathrm{C}$ and $15^{\circ} \mathrm{C}$, while the expedited experiment was performed at $25^{\circ} \mathrm{C}$ and $35^{\circ} \mathrm{C}$. The storage temperature of $10^{\circ} \mathrm{C}$ is the maximum limit in a refrigerated environment; $15^{\circ} \mathrm{C}$ was used to simulate storage conditions in refrigerated shelves in distributing markets, considering that most dairy products have a surface temperature greater than $10^{\circ} \mathrm{C}$ (Korea Consumer Agency, 2007). To simulate the scenario of the consumer leaving the product at room temperature, we used a set temperature of $25^{\circ} \mathrm{C}$. Butter and cheese samples used for experimentation were kept for $221 \mathrm{~d}$ at $10^{\circ} \mathrm{C}$ and $15^{\circ} \mathrm{C}$. Samples that were stored at $25^{\circ} \mathrm{C}$ and $35^{\circ} \mathrm{C}$ were kept for $109 \mathrm{~d}$.

\section{Physicochemical analyses}

To assess changes occurring in the samples over time, acidity, acid value, $\mathrm{pH}$, and moisture content were measured. Lipid oxidation negatively affects product flavor and taste. However, as it plays a crucial part in determining the shelf life of a product, the acid value, acidity, and $\mathrm{pH}$, which are indicators of rancidness, must be analyzed for butter and cheese samples (Panseri et al., 2011). Acidity was measured by adding $10 \mathrm{~mL}$ of distilled water to $10 \mathrm{~mL}$ of the sample along with $0.5 \mathrm{~mL}$ of phenolphthalein, and the solution was titrated with $0.1 \mathrm{~N} \mathrm{NaOH}$ until the reddish color persisted for more than $30 \mathrm{~s}$. The acid value was measured by carefully measuring out $5-10 \mathrm{~g}$ of the sample and adding to an erlenmeyer flask, while also adding $100 \mathrm{~mL}$ of ethanol-ether mixture (1:2) and titrating the solution with a $0.1 \mathrm{~N}$ neutral $\mathrm{KOH}-$ ethanol solution until the reddish color lasted for more than $30 \mathrm{~s}$. The 
moisture content was measured by carefully weighing out 3-5 $\mathrm{g}$ of the sample and placing it in a dry oven set at 98$100^{\circ} \mathrm{C}$ for $3-5 \mathrm{~h}$. The sample was then placed in a desiccator, where it was cooled for approximately $30 \mathrm{~min}$, and then weighed. $\mathrm{pH}$ was measured using a $\mathrm{pH}$ meter. All of the above experiments were conducted based on the livestock processing and compositional standards as defined by the Animal and Plant Quarantine Agency (2012).

\section{Microbiological analysis}

To observe the microbiological activity over time, the number of total bacteria, coliform, and growth of Listeria monocytogenes (L. monocytogenes) was monitored. The number of bacteria was counted by plating the solution on Plate Count Agar (Difco, USA) and incubating at $37^{\circ} \mathrm{C}$ for approximately $48 \mathrm{~h}$. Plates with 25-250 colonies were counted and multiplied by the dilution factor to determine the actual colony count. Coliform count was performed by homogenizing the undiluted solution and then diluting by decimal dilution. The resulting in Lis. monocytogenes dilutions were plated on PALCAM agar plates with supplement (Difco, USA) and incubated at $35^{\circ} \mathrm{C}$ for $24 \mathrm{~h}$. Colonies with a dark brownish or blackish ring were counted and multiplied by the dilution factor to obtain the total number of colonies. All microbiological tests were carried out according to the livestock processing and composition standards (Animal and Plant Quarantine Agency, 2012).

\section{Sensory tests}

To determine changes in the quality of each sample, a sensory test was performed using sight (color, luster, appearance, molding, and yeast formation), taste (flavor and sourness), and smell (smell and odor). The sensory analysis was performed by 10 individuals trained in sensory testing and scored based on a 9-point scale, where 9 was "liked extremely," 8 was "liked very much," 7 was "liked moderately," 6 was "liked slightly," 5 was "neither liked nor disliked," 4 was "disliked slightly," 3 was "disliked moderately," 2 was "disliked very much," and 1 was "disliked extremely" (Ministry of Food and Drug Safety, 2011). The examiners were instructed to give the product a score of 5 points when the product had reached its quality limit (Kim et al., 1993, Pérez Elortondo et al., 2007).

\section{Calculation of the appropriate shelf life of butter and cheese}

Each experiment was classified as legal and non-legal. For legal indicators, the samples were considered to have passed quality when the samples were above legal specifications. For non-legal indicators, sensory evaluation and linear regression analysis were used to evaluate the standard value. However, for L. monocytogenes, the Guidelines for Assessing the Microbiological Safety of Readyto-Eat Foods Place on the Market (2009) was referenced to calculate the standard values. Since the shelf life of butter and cheese is greater than 6 mon, a streamlined experiment was conducted as stated in the expiration date selection experiment guidelines, which defines a streamlined process as an experiment conducted in a harsher environment than that of its original environment because its expiration date is longer than three months. The rate constant $(\mathrm{K})$ was calculated using physiochemical, microbiological, and sensory experimental data. The rate constant $(\mathrm{K})$ was derived through a zero-order reaction, which displayed a constant degradation rate regardless of the quality attributes, and a first-order reaction, which showed exponential change in the degradation rate based on the quality attributes. After using the above equations, the reaction rate by temperature and linear regression model of $\ln \mathrm{K}_{1}$ with $1 / \mathrm{T}$ was calculated and chosen as the most reliable order of reaction. The Arrhenius equation was used to select the expiration date according to $\ln \mathrm{K}=\ln \mathrm{A}-(\mathrm{Ea} /$ $\mathrm{R}) \times 1 / \mathrm{T}$ equation for each indicator, where $\mathrm{K}$ is the specific reaction rate, Ea is the activation energy in $\mathrm{kJ} / \mathrm{mol}, \mathrm{R}$ is the gas constant $(1.987 \mathrm{cal} / \mathrm{mol} \mathrm{K})$, and $\mathrm{T}$ is the absolute temperature $\left(\mathrm{K}=273+{ }^{\circ} \mathrm{C}\right)$.

\section{Results and Discussion}

\section{Changes in microbiological quality}

No coliforms or bacteria were detected, indicating that the product is of acceptable quality based on its composition, according to the livestock processing and component standards. Additionally, the non-legal indictor, $L$. monocytogenes, was not detected. Although bacteria and L. monocytogenes were found intermittently in cheese samples after long storage periods, no trends and/or patterns were observed. Coliforms were not detected in cheese samples throughout the storage period (data not shown), while L. monocytogenes was detected intermittently, but did not show a consistent trend (data not shown). Escherichia coli $\mathrm{O} 157: \mathrm{H} 7$ and L. monocytogenes were inoculated into the butter samples, giving initial bacterial counts of $10^{5} \mathrm{CFU} / \mathrm{g}$, and after storage for $21 \mathrm{~d}$ at $4^{\circ} \mathrm{C}$ and $21^{\circ} \mathrm{C}$, all samples except sweet whipped salted butter had a bacterial cell count less than $10^{1} \mathrm{CFU} / \mathrm{g}$ (Sarah et al., 2003). These results indicate that butter and 
cheese do not support bacterial growth. A previous study on the effect of long-term food storage by animals (Lee and Park, 1998) found no bacterial pollutants. This corresponds with the results obtained in this study, indicating that butter and cheese, which have more fat than other products, do not support bacterial growth.

\section{Changes in physicochemical quality}

As a result of physiochemical changes observed in butter samples stored at $10^{\circ} \mathrm{C}, 15^{\circ} \mathrm{C}, 25^{\circ} \mathrm{C}$, and $35^{\circ} \mathrm{C}$, the initial acidity, a legal quality indicator, was $0.51 \mathrm{mg} \mathrm{KOH} / \mathrm{g}$ on $\mathrm{d} 0$, which was much lower than the quality limit of $2.80 \mathrm{mg} \mathrm{KOH} / \mathrm{g}$. After $221 \mathrm{~d}$ of storage at $10^{\circ} \mathrm{C}$, the acidity was 0.67 and at $15^{\circ} \mathrm{C}$, was 0.73 . When stored for 109 $\mathrm{d}$, the acidity was 0.71 at $25^{\circ} \mathrm{C}$ and 1.39 at $35^{\circ} \mathrm{C}$; these results show a tendency towards increased acidity from the initial value, and imply that any increase in the storage temperature rapidly increases the acidity. $\mathrm{pH}$, a nonlegal quality indicator, was 6.96 in the initial butter sample; after storage for $221 \mathrm{~d}$ at $10^{\circ} \mathrm{C}$, it was reduced to 6.33 , and at $15^{\circ} \mathrm{C}$ was 6.31 . Furthermore, sample $\mathrm{pH}$ after storage for $109 \mathrm{~d}$ at $25^{\circ} \mathrm{C}$ was 5.12 and 4.70 at $35^{\circ} \mathrm{C}$, indicating that long-term storage of butter in cold temperatures decreases the $\mathrm{pH}$, while storage at high temperatures results in a greater decrease in $\mathrm{pH}$. Acid value, another non-legal quality indicator, was 0.01 in the initial butter sample. After storage for $221 \mathrm{~d}$ at $10^{\circ} \mathrm{C}$, the acid value was 0.14 , and 0.23 at $15^{\circ} \mathrm{C}$. After storage for $109 \mathrm{~d}$, the acid value of the sample stored at $25^{\circ} \mathrm{C}$ was 0.16 , and 0.84 in the sample stored at $35^{\circ} \mathrm{C}$.

As a result of physiochemical changes was observed in butter samples which was stored at $10^{\circ} \mathrm{C}, 15^{\circ} \mathrm{C}, 25^{\circ} \mathrm{C}$, and $35^{\circ} \mathrm{C}$, pH of the base sample was 5.91, and after storage for $221 \mathrm{~d}$ at $10^{\circ} \mathrm{C}$, was 5.66 , and 5.59 at $15^{\circ} \mathrm{C}$. After $109 \mathrm{~d}$, the sample stored at $25^{\circ} \mathrm{C}$ had a pH of 5.62 while the sample stored at $35^{\circ} \mathrm{C}$ had a pH of 5.49. The results show an inverse relationship between $\mathrm{pH}$ and storage time/ temperature; $\mathrm{pH}$ falls as the storage time increases and a higher storage temperature results in a faster decrease in the $\mathrm{pH}$ value. The initial cheese sample acidity was 0.50 . After $221 \mathrm{~d}$ of storage, the acidity of the sample stored at $10^{\circ} \mathrm{C}$ was 0.80 , whereas at $15^{\circ} \mathrm{C}$, it was 1.00 . After $109 \mathrm{~d}$, the acidity of the sample stored at $25^{\circ} \mathrm{C}$ was 0.94 and 1.13 at $35^{\circ} \mathrm{C}$, indicating that increased storage time increases the acidity and that higher temperatures cause a rapid increase in acidity. The initial cheese sample moisture content, a non-legal indicator, was 50.23. After $221 \mathrm{~d}$ of storage, the moisture content of the sample stored at $10^{\circ} \mathrm{C}$ was 46.65 and 46.53 when the sample was stored at $15^{\circ} \mathrm{C}$. After $109 \mathrm{~d}$, the moisture content of the sample stored at $25^{\circ} \mathrm{C}$ was 47.29 and 46.55 at $35^{\circ} \mathrm{C}$. These results indicate that increased storage time correlated with lower moisture content.

\section{Changes in sensory evaluation}

The sensory evaluation of butter samples, a legal indicator for evaluation, was performed using a 9-point scale (Ministry of Food and Drug Safety, MFDS. 2013), with d 0 scored as 9 points and the sensory quality limit set at 5 points. Butter samples were analyzed after storage at $10^{\circ} \mathrm{C}, 15^{\circ} \mathrm{C}, 25^{\circ} \mathrm{C}$, and $35^{\circ} \mathrm{C}$. The butter sample stored at $10^{\circ} \mathrm{C}$ scored 9 points for $67 \mathrm{~d}$ whereas the sample stored at $15^{\circ} \mathrm{C}$ scored 9 points for only $63 \mathrm{~d}$. After the mentioned dates, the samples stored at $10^{\circ} \mathrm{C}$ and $15^{\circ} \mathrm{C}$ were above the quality limit of 5 points until $221 \mathrm{~d}$, while the sample stored at $25^{\circ} \mathrm{C}$ dropped to 5 points in $1 \mathrm{~d}$. Also, the sample stored at $35^{\circ} \mathrm{C}$ reached the sensory quality limit after $1 \mathrm{~d}$. Sensory evaluation of cheese samples was analyzed after storage at $10^{\circ} \mathrm{C}, 15^{\circ} \mathrm{C}, 25^{\circ} \mathrm{C}$, and $35^{\circ} \mathrm{C}$. The cheese sample stored at $10^{\circ} \mathrm{C}$ scored 9 points for 88 $\mathrm{d}$, while those stored at $15^{\circ} \mathrm{C}, 25^{\circ} \mathrm{C}$, and $35^{\circ} \mathrm{C}$ scored 9 points up to 81,53 , and $46 \mathrm{~d}$, respectively. The quality of these samples dropped after the above dates, with scores lower than 5 points.

\section{Calculated actual shelf life}

Linear regression analysis was performed based on the storage time. Calculated quality indicator standard values were used in the linear regression equation to determine the quality limit date. The linear regression equation for butter was shown in Table 1. After storage of butter and cheese samples at $10^{\circ} \mathrm{C}, 15^{\circ} \mathrm{C}, 25^{\circ} \mathrm{C}$, and $35^{\circ} \mathrm{C}$, the acid value, appearance, acidity, and $\mathrm{pH}$ were evaluated for the butter samples, while the sensory evaluation, moisture content, and acidity were evaluated for the cheese samples. The data were then used to calculate a linear regression graph based on the storage time. Counts of coliforms, total bacteria, and L. monocytogenes, which were never found, were excluded from the quality limit decision process. The expiration date was typically decided via determining a proper quality indicator and measuring the point at which the product loses its value by sensory evaluation. In this study, compositional specifications of the "Animal and Plant Quarantine Agency, Process Criteria and Ingredient Standard of Livestock Products" were used as quality indicators to determine the quality limit when the product reached the legal specification, and the results of the quality limit date based on the legal specifi- 
Table 1. Shelf life of butter and cheese samples stored at $10^{\circ} \mathrm{C}, 15^{\circ} \mathrm{C}$, and $25^{\circ} \mathrm{C}$ by legal quality limit

\begin{tabular}{|c|c|c|c|c|}
\hline & Quality criteria & Temperature $\left({ }^{\circ} \mathrm{C}\right)$ & Quality limit $^{2)}$ & Estimated shelf life (mon) \\
\hline \multirow{6}{*}{ Butter } & \multirow{3}{*}{ Acid value } & 10 & 2.80 & 107.80 \\
\hline & & 15 & 2.80 & 93.53 \\
\hline & & 25 & 2.80 & 50.57 \\
\hline & \multirow{3}{*}{$\begin{array}{l}\text { Sensory overall } \\
\text { evaluation }^{1)}\end{array}$} & 10 & 5 & 21.94 \\
\hline & & 15 & 5 & 17.38 \\
\hline & & 25 & 5 & 7.14 \\
\hline \multirow{3}{*}{ Cheese } & \multirow{3}{*}{$\begin{array}{l}\text { Sensory overall } \\
\text { evaluation }\end{array}$} & 10 & 5 & 23.98 \\
\hline & & 15 & 5 & 17.88 \\
\hline & & 25 & 5 & 6.51 \\
\hline
\end{tabular}

${ }^{1)}$ Penal number $=10 ; 1=$ very different from control, $5=$ different from control (quality limit of overall sensory evaluation), $9=$ same as control.

${ }^{2)}$ Legal quality limit: "Process Criteria and Ingredient Standard of Livestock Products" by Animal, Plant and Fisheries Quarantine and Inspection Agency.

Table 2. Shelf life of butter and cheese samples stored at $10^{\circ} \mathrm{C}, 15^{\circ} \mathrm{C}$, and $25^{\circ} \mathrm{C}$ by non-legal quality limit

\begin{tabular}{|c|c|c|c|c|c|c|}
\hline & $\begin{array}{l}\text { Quality } \\
\text { criteria }\end{array}$ & $\begin{array}{c}\text { Temperature } \\
\left({ }^{\circ} \mathrm{C}\right)\end{array}$ & $\begin{array}{l}\text { Quality } \\
\text { limit }^{1)}\end{array}$ & Regression equation & $\begin{array}{l}\text { Correlation } \\
\text { coefficient }\end{array}$ & $\begin{array}{c}\text { Estimated shelf } \\
\text { life (mon) }\end{array}$ \\
\hline \multirow{6}{*}{ Butter } & \multirow{3}{*}{$\mathrm{pH}$} & 10 & 3.55 & $y=-0.0037 \times+6.9999$ & 0.8529 & 31.10 \\
\hline & & 15 & 3.94 & $y=-0.0043 x+7.0717$ & 0.8425 & 24.25 \\
\hline & & 25 & 4.62 & $y=-0.012 x+7.235$ & 0.6279 & 7.28 \\
\hline & \multirow{3}{*}{ Acidity } & 10 & 0.41 & $y=0.0005 \times+0.0474$ & 0.5671 & 24.23 \\
\hline & & 15 & 0.43 & $y=0.001 \times+0.0295$ & 0.9030 & 13.19 \\
\hline & & 25 & 0.23 & $\mathrm{y}=0.0011 \times+0.0285$ & 0.6070 & 6.10 \\
\hline \multirow{9}{*}{ Cheese } & \multirow{3}{*}{$\mathrm{pH}$} & 10 & 4.35 & $y=-0.0018 \times+5.9693$ & 0.6578 & 29.98 \\
\hline & & 15 & 4.98 & $y=-0.0019 x+5.9585$ & 0.8681 & 17.18 \\
\hline & & 25 & 5.43 & $y=-0.0029 x+5.9241$ & 0.9205 & 5.71 \\
\hline & \multirow{3}{*}{$\begin{array}{l}\text { Moisture } \\
\text { content }\end{array}$} & 10 & 44.82 & $y=-0.0165 x+50.167$ & 0.9802 & 10.81 \\
\hline & & 15 & 45.42 & $y=-0.0163 \times+50.078$ & 0.9873 & 9.47 \\
\hline & & 25 & 45.16 & $y=-0.0299 x+50.078$ & 0.9308 & 5.48 \\
\hline & \multirow{3}{*}{ Acidity } & 10 & 1.04 & $y=0.0007 x+0.6358$ & 0.4596 & 19.21 \\
\hline & & 15 & 1.16 & $y=0.0018 x+0.6263$ & 0.8655 & 9.83 \\
\hline & & 25 & 1.03 & $y=0.0027 x+0.6528$ & 0.6081 & 4.64 \\
\hline
\end{tabular}

${ }^{1)}$ Quality limit: Estimated by regression analysis between non-legal quality criteria (y) and overall sensory evaluation (x) during the storage period.

cations are presented in Table 1. In case of butter, acid value and sensory evaluation, which are both legal specifications, showed the following results: expiration date of the sample stored at $10^{\circ} \mathrm{C}$ was $107.80 \mathrm{mon}$ (based on acid value) and 21.94 mon (based on sensory evaluation); at $15^{\circ} \mathrm{C}$, it was 93.53 mon (based on acid value) and 17.38 mon (based on sensory evaluation); and at $25^{\circ} \mathrm{C}$, it was 50.57 mon (based on acid value) and 7.14 mon (based on sensory evaluation). For quality indicators that do not have legal specifications, a linear digression equation was calculated based on quality indicators and the 9-point scale. The expiration date was determined by inserting the quality limit of 5 points into the linear digression equation (Table 2). In case of butter, measurements of acidity and $\mathrm{pH}$, which are non-legal quality indicators, showed that the expiration dates of butter samples were 31.10 mon (based on $\mathrm{pH}$ ) and 24.23 (based on acidity) when stored at $10^{\circ} \mathrm{C} ; 24.25$ and 13.19 mon when stored at $15^{\circ} \mathrm{C} ; 7.28$ and $6.10 \mathrm{mon}$ when stored at $25^{\circ} \mathrm{C}$. The quality limit was determined using the indicator that gave the shortest quality limit date. Therefore, when using sensory evaluation as the indicator, the quality limit date for samples stored at $10^{\circ} \mathrm{C}$ was 21.94 mon, which was the shortest limit when compared to results obtained using other indicators. The quality limit date for samples stored at $15^{\circ} \mathrm{C}$ using acidity as the indicator was 13.19 mon, which was the shortest result. Similarly, the quality limit date for samples stored at $25^{\circ} \mathrm{C}$, with acidity as the indicator, was the lowest at 6.10 mon. The quality limit of cheese was also determined in a similar manner. In case of cheese, sensory evaluation, which are only legal specifications, showed the following results: expiration date of the sample stored at $10^{\circ} \mathrm{C}$ was $23.98 \mathrm{mon}$, at $15^{\circ} \mathrm{C}$, it was $17.88 \mathrm{mon}$; and at $25^{\circ} \mathrm{C}$, it was $6.51 \mathrm{mon}$. For quality 
indicators that do not have legal specifications, a linear digression equation was calculated based on quality indicators and the 9-point scale. In case of non-legal biomarker, for samples stored in $10^{\circ} \mathrm{C}, 15^{\circ} \mathrm{C}$ and $25^{\circ} \mathrm{C}$, the quality limit based on the acidity, $\mathrm{pH}$, and moisture which are non-legal quality indicators. It showed that the expiration dates of cheese sample were 29.98 (based on $\mathrm{pH}$ ), 10.81 (based on moisture contents) and 19.21 mon (based on acidity) when stored at $10^{\circ} \mathrm{C} ; 17.18,9.47$ and 9.83 mon when stored at $15^{\circ} \mathrm{C} ; 5.71$ (based on $\mathrm{pH}$ ), 5.48 (based on moisture contents), and 4.64 (based on acidity) when stored at $25^{\circ} \mathrm{C}$. The quality limit was determined using the indicator that gave the shortest quality limit date. As a result, using moisture contents as the indicator, the quality limit date for samples stored at $10^{\circ} \mathrm{C}$ was 10.81 mon, which was the shortest limit when compared to results obtained using other indicators. The quality limit date for samples stored at $15^{\circ} \mathrm{C}$ using moisture contents as the indicator was 9.47 mon, which was the shortest result. Similarly, the quality limit date for samples stored at $25^{\circ} \mathrm{C}$, with acidity as the indicator, was the lowest at 4.64 mon.

\section{Calculation of accelerative experimental shelf life}

The sample stored at $35^{\circ} \mathrm{C}$ was tested using an accelerated model to find the quality limit date (Table 3). Ac- cording to zero-order and first-order reactions, the product with the largest $\mathrm{R}^{2}$ was chosen and used to determine the quality limit by the equation $\ln \mathrm{K}=-(\mathrm{Ea} / \mathrm{R}) \times 1 / \mathrm{T}+\ln \mathrm{A}$. For butter samples, the quality limit was based on the first-order acid value, zero-order appearance, zero-order $\mathrm{pH}$, and first-order acidity. In case of butter, the zeroorder acid value showed a quality limit of $9.92 \mathrm{mon}$, while zero-order sensory estimated $1.83 \mathrm{mon}$. Also, the zero-order $\mathrm{pH}$ estimated a quality limit of $0.58 \mathrm{mon}$, and first order acidity estimated a quality limit of 2.75 . In case of cheese, the zero-order sensory value showed a quality limit of 3.49 mon, while first-order estimated 4.22 mon. Also, the zero-order moisture content estimated a quality limit of 4.28 mon, and zero order acidity estimated a quality limit of 0.20 mon.

Accordingly, the shortest quality limit date (by acidity) was chosen as the quality limit. After considering factors that may cause quality changes, such as characteristics, distribution process, and the risk involved (Kim et al., 1993), a safety factor under one was chosen as an expiration date multiplication factor. As a result, Table 4 shows the shelf-life, estimated as the earliest date among all date of quality limit when each quality criteria were reached to quality limit. Shelf-life of butter was estimated after 21.94 mon at $10^{\circ} \mathrm{C}, 17.18$ mon at $15^{\circ} \mathrm{C}, 6.10$ mon at $25^{\circ} \mathrm{C}$, and $0.58 \mathrm{mon}$ at $35^{\circ} \mathrm{C}$; that of cheese was estimated after

Table 3. Shelf life of butter and cheese samples stored at $35^{\circ} \mathrm{C}$ using an accelerated experiment

\begin{tabular}{|c|c|c|c|c|c|c|}
\hline & Qua & riteria & Order of reaction & $\mathrm{K}^{3)}$ & $A_{0}^{4)}-A_{t}^{5)}$ & $\begin{array}{c}\text { Estimated shelf } \\
\text { life (mon) }\end{array}$ \\
\hline \multirow{8}{*}{ Butter } & \multirow{4}{*}{$\begin{array}{c}\text { Legal } \\
\text { quality limit }^{1)}\end{array}$} & \multirow{2}{*}{ Acid value } & Zero order & 0.00956 & 2.85 & 9.92 \\
\hline & & & First order & -6.38620 & 0.54 & 10.75 \\
\hline & & \multirow{2}{*}{$\begin{array}{l}\text { Sensory overall } \\
\text { evaluation }\end{array}$} & Zero order & 0.00541 & 0.30 & 1.83 \\
\hline & & & First order & -3.44790 & 3.43 & 3.59 \\
\hline & \multirow{4}{*}{$\begin{array}{c}\text { Non-legal } \\
\text { quality limit }{ }^{2)}\end{array}$} & \multirow{2}{*}{$\mathrm{pH}$} & Zero order & 0.13224 & 2.29 & 0.58 \\
\hline & & & First order & -3.23640 & 1.70 & 1.44 \\
\hline & & \multirow{2}{*}{ Acidity } & Zero order & 0.04105 & 4.00 & 3.25 \\
\hline & & & First order & -4.94250 & 0.59 & 2.75 \\
\hline \multirow{8}{*}{ Cheese } & \multirow{3}{*}{$\begin{array}{c}\text { Legal } \\
\text { quality limit }\end{array}$} & \multirow{2}{*}{$\begin{array}{l}\text { Sensory overall } \\
\text { evaluation }\end{array}$} & Zero order & 0.03816 & 4.00 & 3.49 \\
\hline & & & First order & -5.30120 & 0.59 & 3.93 \\
\hline & & \multirow{2}{*}{$\mathrm{pH}$} & Zero order & 0.00381 & 0.50 & 4.35 \\
\hline & \multirow{5}{*}{$\begin{array}{l}\text { Non-legal } \\
\text { quality limit }\end{array}$} & & First order & -7.27410 & 0.09 & 4.22 \\
\hline & & \multirow{2}{*}{ Moisture content } & Zero order & 0.03706 & 4.76 & 4.28 \\
\hline & & & First order & -7.20000 & 0.10 & 4.45 \\
\hline & & \multirow{2}{*}{ Acidity } & Zero order & 0.12185 & 0.72 & 0.20 \\
\hline & & & First order & -3.34640 & 0.89 & 0.84 \\
\hline
\end{tabular}

${ }^{1)}$ Legal quality limit: "Process Criteria and Ingredient Standard of Livestock Products" by Animal, Plant and Fisheries Quarantine and Inspection Agency.

${ }^{2)}$ Non-legal quality limit: Estimated by regression analysis between quality criteria $(\mathrm{y})$ and overall sensory evaluation (x) during the storage period.

${ }^{3)} \mathrm{K}$ : rate constant.

${ }^{4)}$ Initial date of index quality attribute.

${ }^{5)}$ date of index quality attribute as t time passes. 
Table 4. Estimated shelf-life of butter and cheese at $10^{\circ} \mathrm{C}, 15$ ${ }^{\circ} \mathrm{C}, 25^{\circ} \mathrm{C}$, and $35^{\circ} \mathrm{C}$

\begin{tabular}{ccc}
\hline \hline \multirow{2}{*}{ Temperature $\left({ }^{\circ} \mathrm{C}\right)$} & \multicolumn{2}{c}{ Shelf life (months) } \\
\cline { 2 - 3 } & Butter & Cheese \\
\hline 10 & 21.94 & 10.81 \\
15 & 17.18 & 9.47 \\
25 & 6.10 & 4.64 \\
35 & 0.58 & 0.20 \\
\hline
\end{tabular}

$10.81 \mathrm{mon}$ at $10^{\circ} \mathrm{C}, 9.47 \mathrm{mon}$ at $15^{\circ} \mathrm{C}, 4.64 \mathrm{mon}$ at $25^{\circ} \mathrm{C}$, and $0.20 \mathrm{mon}$ at $35^{\circ} \mathrm{C}$. Finally, shelf-life can established to applied safety factor $(<1)$, as shelf life can change due to factors or other quality standard criteria. Therefore, although it can not be applied to all butter and cheese products, there has been no report that butter and cheese has previously been researched on establishment in shelf life. Taken together, these results suggest that serve a basis data in establishment shelf life on butter and cheese.

\section{Acknowledgements}

This paper was supported by Konkuk University in 2014.

\section{References}

1. Bernues, A., Olaizola, A., and Corcoran, K. (2003) Labelling information demanded by European consumers and relationships with purchasing motives, quality and safety of meat. Meat Sci. 65, 1095-1106.

2. Codex. (2010) General Standard for the Labeling of Prepackaged Food, Codex Stain 1-1985.

3. Choi, S. H. (2004) Scientific consideration in determining shelf life of market milk. J. Korean Dairy Technol. Sci. 22, 27-35.

4. Chung, C. I., Kim, K. T., Cho, N. Y., Jung, M. J., Oh, H. S., and Lee, G. (2002) Comparison of the keeping quality of UHT pasteurized milks in Korea. Korean J. Food Sci. Ani. Resour. 22, 247-251.

5. Groth, E. (2014) Institutions Involved in Food Safety: Consumer organizations, Encyclopedia of Food Safety, 4, 369-372.

6. Health Protect Agency. (2009) Guideline for assessing the microbiological safety of ready-to-eat foods placed on the market.

7. Hwang, T. H. and Park K. H. (2007) Harmonization of date marking for export of Korean foods. Food Ind. Nutr. 12, 12-18.

8. Krause, A. J., Miracle, R. E., Sanders T. H., Dean L. L., and Drake M. A. (2008) The effect of refrigerated and frozen storage on butter flavor and texture, J. Dairy Sci. 91, 455-465.

9. Kim, K. D. and Lee, J. Y. (2010) A survey on the housewives' purchasing behavior and needs for food safety information. J. Korean Soc. Food Sci. Nutr. 39, 392-398.

10. Kim, K. O., Kim, S. S., Sung, N. K., and Lee, Y. C. (1993) Methods and Applications of Sensory Evaluation, Shinkwang
Publishing Co., Seoul, Korea. pp. 326-327.

11. Korea Consumer Agency. (2007) Monitoring of microbiological change in food according to distribution temperature. Korea Consumer Agency, Seoul, Korea. pp. 7-10.

12. Kwun, J. W. and Lee, C. H. (2007) Trends of Recent FoodBorne Disease Outbreaks in Korea. J. Korean Med. Assoc. 50, 573-581.

13. Lee, K. A. and Kim, H. S. (2001) Consumers' understanding and preference for shelf life and ingredient listings in food label. Korean J. Soc. Food Cookery Sci. 17, 405-411.

14. Lee, Y. W. and Park S. G. (1998) Distribution of Indicator Organisms and Influence of Storage Temperature and Period in Commercial Animal Foods. J. Food Hyg. Safety. 13, 430-440.

15. Lim, J. M. (2003) Present condition after liberalization of shelf-life of milk product in Korea. J. Korean Dairy Technol. Sci. 21, 120-124.

16. Labuza T. P. and Fu, B. (1993) Growth-kinetics for shelf life prediction - theory and practice. J. Ind. Microbiol. 12, 309323.

17. Ministry of Food and Drug Safety, MFDS. (2013) Food Code. Chungcheongbuk-do, Korea.

18. Park, H. O., Kim, C. M., Woo, G. J., Park, S. H., Lee, D. H., Chang, E. J., and Park, K. H. (2001) Monitoring and Trends Analysis of Food Poisoning Outbreaks Occurred in Recent Years in Korea. J. Fd. Hyg. Safety. 16, 280-294.

19. Park, H. R. and Min, Y. H. (1995) A basic research for the adoption and implementation of nutrition labeling: with a reference to the consumer awareness. J. Korean Soc. Food Sci. Nutr. 10, 155-166.

20. Panseri, S., Soncin, S., Chiesa, M. L., and Biondi, P. A. (2011) A headspace solid-phase microextraction gas-chromatographic mass-spectrometric method (HS-SPME-GC/MS) to quantify hexanal in butter during storage as marker of lipid oxidation. Food Chem. 127, 886-889.

21. Pérez Elortondoa, F. J., Ojedaa, M., Albisua, M., Salmeróna, J., Etayoa, I., and Molinab, M. (2007) Food quality certification: An approach for the development of accredited sensory evaluation methods. Food Qual. Prefer. 18, 425-439.

22. QIA. (2011) Process Criteria and Ingredient Standard of Livestock Products. 2011-105. Animal, Plant and Fisheries Quarantine and Inspection Agency, Anyang, Korea.

23. Sikorski, Z., Kolakowska, A., and Burt, J. E. (1989) Postharvest biochemical and microbial changes Seafood: Resources, nutritional composition and preservation, CRC Press, Gdansk, Poland. pp. 55-72.

24. Evert-Arriagada, K., Hernández-Herrero, M. M., Guamis, B., and Trujillo, A. J. (2014) Commercial application of high-pressure processing for increasing starter-free fresh cheese shelflife. LWT-Food Sci. Technol. 55, 498-505.

25. Sarah, L. H., Barbara B. A., and Larry, R. B. (2003) Viability of Salmonella, Escherichia coli O157:H7, and Listeria monocytogenes in butter, yellow fat spreads, and margarine as affected by temperature and physical abuse. Food Microbiol. 20, 159168.

(Received 2014.3.21/Revised 2014.4.1/Accepted 2014.4.3) 